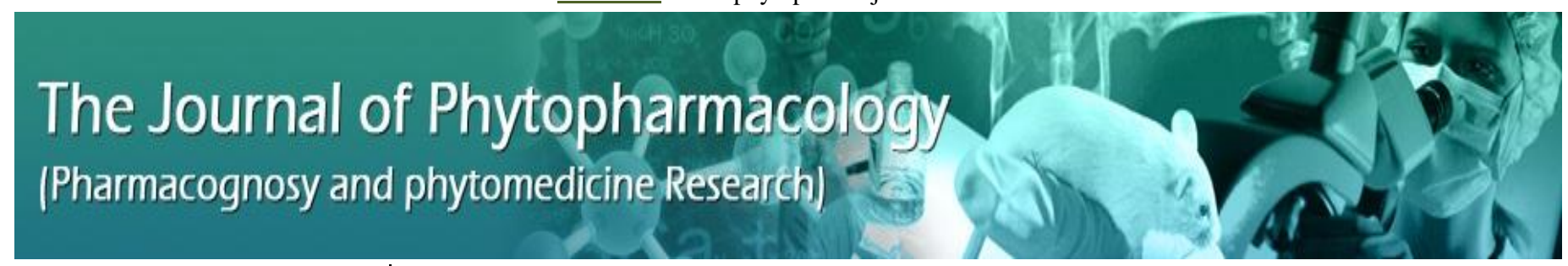

\section{Research Article}

ISSN $2230-480 \mathrm{X}$

JPHYTO 2016; 5(3): 112-116

May- June

(c) 2016, All rights reserved

\section{G.M. Masu d Parvez}

Department of Phamacy, Varendra University, Rajshahi, Bangladesh

Dr. Ashik Mosaddik

Department of Phamacy, Rajshahi University, Rajshahi, Bangladesh

\title{
Evaluation of anticancer property of mango peel and flesh after formalin treatment
}

\author{
G.M. Masud Parvez, Ashik Mosaddik
}

\section{ABS TRACT}

Cancer is life threatening disease an d the second leading cause of death. Various phenolic compounds obtained from plant sources such as fruit, bark, leaf and roots acts against cancer but when such fruits are treated with some chemicals such as formalin which itself a carcinogenic agent changes antioxidant potential of that fruit. To evaluate the change of anticancer potential fresh raw mangoes are collected and treated with formalin for 7 days and various parameters such as tumour cell growth inhibition, increase life span are measured. Vario us haematological parameters such as red blood cell, white blood cell and haemoglobin content is measured. It is found that normal mango peel contain higher anticancer property as compare to mango flesh. But when this mango peel is treated with formalin, its anticancer potential is decreases, not only in the peel but also in the flesh, which suggests the presence of formalin in mango flesh. From the study it is observed that normal mango peel (NP) causes significant inhibition of tumor cell growth $(76.74 \%)$ and sufficiently increases life span $(76.00 \%)$ at $100 \mathrm{mg} / \mathrm{kg}$ daily dose whereas formalin treated peel (FP) causes (52.69\%) tumour cell growth inhibition and increases lifespan (57.29\%) at the same dose. On haematological study, normal mango peel increases red blood cell and Haemoglobin content and decreases white blood cell content but formalin treated sample does not make sufficient change. The anti-cancer activity shows a direct correlation with the dose

Keywor ds: Mango, formalin, anticancer, haemat ological.

\section{INTRODUCTION}

Research is now focusing on the search for new types of natural chemotherapeutic agent that is plant based medicines which are proving to be excellent sources of new compounds. A survey lists over 1400 genera of herbs that have a history of use in cancer treatments ${ }^{[1]}$. Cancer continues to represent the one of the largest cause of mortality in the world and claims over 6 million lives each year ${ }^{[2]}$. In 2007 , cancer caused about $13 \%$ of all human deaths worldwide $(7.9$ million) and the rates are rising in the developing world ${ }^{[3]}$. In 2008, approximately 12.7 million cancers were diagnosed (excluding nonmelanoma skin cancers and other non-invasive cancers), and in 2010 nearly 7.98 million people died ${ }^{[4}$ ]. In 2012, 8.2 million people died due to cancer throughout the world ${ }^{[5]}$. Recent data suggests that 196,900 peoples are diagnosed of cancer and 78,000 deaths are occurred in Canada in 2015 due to cancer ${ }^{[6]}$, while in 2012, 186,400 new cases of cancer (excluding non-melanoma skin cancer) was diagnosed and 75,700 cancer deaths was occured in Canada ${ }^{[7]}$. In 2015 about 1,658,370 new cases of cancer have been identified and about 589,430 peoples are died in United States ${ }^{[8]}$. In Australia, 130,470 new cases of cancer was diagnosed in 2015 , with that number set to rise to 150,000 by $2020^{[9]}$.

Particular substances have been linked to specific types of cancer. Tobacco smoking is associated with many forms of cancer ${ }^{[10]}$ and causes $90 \%$ of lung cancer ${ }^{[11]}$. In Western Europe $10 \%$ of cancers in males and $3 \%$ of cancers in females are attributed to alcohol ${ }^{[12]}$. Cancer related to one's occupation is believed to represent between $2-20 \%$ of all cases ${ }^{[13]}$. Physical inactivity is believed to contribute to cancer risk not only through its effect on body weight but also through negative effects on immune system and endocrine system ${ }^{[14]}$. A high-salt diet is linked to gastric cancer, aflatoxin B1, a frequent food contaminate, with liver cancer, and betel nut chewing with oral cancer ${ }^{[15]}$. Gastric cancer is more common in Japan due to its high-salt diet ${ }^{[16]}$ and colon cancer is more common in the United States. Bacterial infection may also increase the risk of cancer, as seen in Helicobacter pylori induced gastric carcinoma ${ }^{[17]}$. Parasitic infections strongly associated with cancer include Schistosoma haematobium (squamous cell carcinoma of the bladder) and the liver flukes ${ }^{[18]}$. Less than $0.3 \%$ of the population are carriers of a genetic mutation which has a large effect on cancer risk and this cause less than 3-10\% of all cancer ${ }^{[19]}$. Usually, physical carcinogens such as asbestos, fib ers, glass wool and rock wool also cause to develop cancer ${ }^{[20]}$.

\section{Correspondence:}

G.M. Masu d Parvez

Department of Phamacy,

Varendra University, Rajshahi, Bangladesh

Email: masud.ph.ru[at]gmail.com
From newspaper report it is found that mango, one of the most cultivated fruits in the world along with other fruits such as litchi, blackberry are regularly treated with formalin to keep them stay for long time. A survey in 26 markets in Dhaka city by environment protective agency "Save the Environment 
Movement" (SEM) during June 1 to 10,2013 found that around 94 percent of the mangoes and 100 percent blackberries and litchis are formalin-tainted ${ }^{[21]}$. A similar result is found in the following year, tests conducted by Poribesh Bachao Andolon (POBA) from June 1 and June 10, 2014 show that, all the black berries and 95 percent litchis sold in 35 city kitchen markets of Dhaka city contained formalin ${ }^{[22]}$. Literature reports suggests that there is sufficient study about anticancer activities of mango but there is no study about the anticancer potentials of mango after formalin treatment ${ }^{[23-26]}$. The objective of the present study is to find out the effects of formalin on anticancer property of mango.

\section{MATERIALS AND METHODS}

\section{Collection of plant material}

About $10 \mathrm{~kg}$ of raw mango was collected from the garden as pure state and it does not contain any foreign chemical. After collecting the mango were washed out in distilled water and shed dried. The mango was divided into two groups, one group is treated with formalin for 7 days and other group was kept as normal. The formalin solution was sprayed by the spray gun. Both groups of mangoes were peeled off and peels and fleshes are oven dried at $55^{\circ} \mathrm{C}$. The peels and flesh of each group are then ground into coarse powder. The samples are then extracted by ethanol under sonication bath and filtered. The filtrate was then concentrated with a rotary evaporator under reduced pressure at $50^{\circ} \mathrm{C}$ to obtain brownish mass of peels and reddish mass of flesh.

\section{Transplantation of ascite tumour}

Ascitic fluid was drawn out from different tumour bearing Swiss albino mice at the respective log-phases of tumour cells. A $3 \mathrm{ml}$ syringe filled with 20 gauge needle was used for this tumour cell aspiration. The freshly drawn fluid was diluted with normal saline $(0.98 \% \mathrm{NaCl}$ solution) and the tumour cells number was adjusted to approximately $2 \times 10^{6}$ cells / $\mathrm{ml}$ by counting the cell number with the help of a haemocy tometer. The viability of tumour cells was observed by trypen blue dye $(0.4 \%)$ exclusion assay. Cell sample showing above $90 \%$ viability were used for transplantation. Tumour suspension of $0.1 \mathrm{ml}$ was injected intraperitoneally (i. p.) to each Swiss albino mouse. Strict aseptic condition was maintained throughout the transplantation process.

\section{Preparation of stock solution}

For therapeutic treatment, stock solution of bleomycin was made by using distilled water at the concentration of $0.075 \mathrm{mg} / \mathrm{ml}$. Crude mango extract was dissolved in pure distilled water at the concentrations of $6.25 \mathrm{mg} / \mathrm{ml}$ and $12.5 \mathrm{mg} / \mathrm{ml}$.

\section{Determination of cell growth inhibition}

To determine the cell growth inhibition, six groups of Swiss albino mice (6 in each group) weighing 20-25 gm were used. For therapeutic evaluation $13.6 \times 10^{4}$ EAC cells in every mouse were inoculated into each group of mice on day " 0 ". Treatments were started after 24 hours of tumour inoculation and continued for five days. Group one to four received the test compound at the doses of $50 \mathrm{mg} / \mathrm{kg}$ (i. p), and 100 $\mathrm{mg} / \mathrm{kg}$ (i. p). Group five received bleomycin at the dose of $0.3 \mathrm{mg} / \mathrm{kg}$ (i. p) and group six was used as control. Mice in each group were sacrificed on day six and the total intra peritoneal tumour cells were harvested by normal saline $(0.98 \%)$. Viable cells were first identified by using trypen blue and then counted by a haemocytometer. Total number of viable cells in every animal of the treated groups was compared with those of control (EAC treated only) group.

\section{Determination of survival time and increase lifespan}

For this determination, ${ }^{[27]}$ method was followed. Tumour growth were monitored and host survival was recorded and expressed as mean survival time in days and percent increase of life span was calculated by using the following formulae:

$$
\begin{aligned}
& \text { Mean survival time }(\text { MST })=\frac{\sum \text { Survival time (days ) of each mouse in a group }}{\text { Total number of mice }} \\
& \text { Percent increase of life span (ILS) } \%=\left(\frac{\text { MST of treated group }}{\text { MST of control group }}-1\right) \times 100
\end{aligned}
$$

\section{Determination of haematological parameter}

Haematological parameters were studied in both normal and tumour bearing mice. In case of tumour bearing mice, treatment was started after 24 hours of EAC cell transplantation and continued for 10 days. Blood was drawn from each group of mice on day 12 by tail puncture and determined Haemoglobin, Red blood cell and White blood cell content.

\section{Total Red blood cell count}

Exactly $10 \mu 1$ non coagulating blood was drawn with the tip of a micropipette and diluted to 1000 times with red cell counting fluid. $\mathrm{RBC}$ was counted with hemocytometer and the number of cells was counted with a microscope.

\section{Total White blood cell count}

Exactly $10 \mu \mathrm{l}$ non coagulating blood was drawn with the tip of a micropipette and diluted with $1 \mathrm{ml} \mathrm{WBC}$ counting fluid and mixed properly; the resultant mixture was checked in Neubauer haemocytometer and the number of cells was counted with a microscope. The dilution factor was 100 . Total WBC cells per ml were calculated.

\section{Estimation of haemoglobin}

The amount of haemoglobin was measured by using Sahling's hemometer. Blood was drawn into the pipette up to the mark and transferred to the cuvette (tube) in haemometer containing a little amount of N/10 HCl. Distilled water was added and stirred until a good colour match was obtained. The final reading of the solution in the cuvette was noted. From the cuvette reading gram \% $(\mathrm{gm} / \mathrm{dl})$ of haemoglobin was calculated.

\section{RESULTS}

\section{Effects on cell growth inhibition}

Effect of the extracts and bleomycin on the EAC cell growth on day six after tumour transplantation are shown in the figure 1.

Treatment with ethanolic extract of NP resulted in maximum cell inhibition at the doses $100 \mathrm{mg} / \mathrm{kg}$ (i.p) and $50 \mathrm{mg} / \mathrm{kg}$ (i.p) as evident from $76.74 \%$ and $40.35 \%$ reduction of tumour cells respectively whereas the same extract with formalin treated show marked reduction of cell growth inhibition as $52.69 \%$ and $29.35 \%$ respectively. The normal mango flesh show activity of some extent but the activity of formalin treated flesh is negligible. Bleomycin $(0.3 \mathrm{mg} / \mathrm{kg}$ ) showed cell growth inhibition by $86.28 \%$ (data not shown in the figure).

\section{Effects on survival time}

The ethanolic extract of normal mango peel shows a significant increase on survival time of EAC cell bearing mice are shown in the figure 2. It has been observed that tumour induced mouse treated with 
the ethanolic extract of normal mango peel at doses of $100 \mathrm{mg} / \mathrm{kg}$ (i.p) and $50 \mathrm{mg} / \mathrm{kg}$ (i.p) resulted in increase of life span significantly which are $76.00 \%$ and $44.79 \%$ respectively, when compared to that of control mice. The formalin treated mango peel show moderate degree of increase life span $57.29 \%$ and $28.13 \%$ at doses of $100 \mathrm{mg}$ $/ \mathrm{kg}$ (i.p) and $50 \mathrm{mg} / \mathrm{kg}$ (i.p) (figure 3) whereas the effect of other extract is not significant. The survival time increased when the dose of the extract is increased but treatment with formalin treated extract decreases the life span as compared to normal extract. Bleomycin increased the life span by $84.38 \%$ (data not shown in the figure) when compared to the control.

\section{Effects on haematological parameter}

Haematological parameters were found to be altered from normal values along with the growth of tumour. Haemoglobin and RBC count were found to be decreased and WBC count increased after the inoculation of EAC cells in Swiss albino mice. After treatment with the test extracts at doses $50 \mathrm{mg} / \mathrm{kg}$ (i.p) and $100 \mathrm{mg} / \mathrm{kg}$ (i.p), it was found that the parameters restored moderately only at high doses.

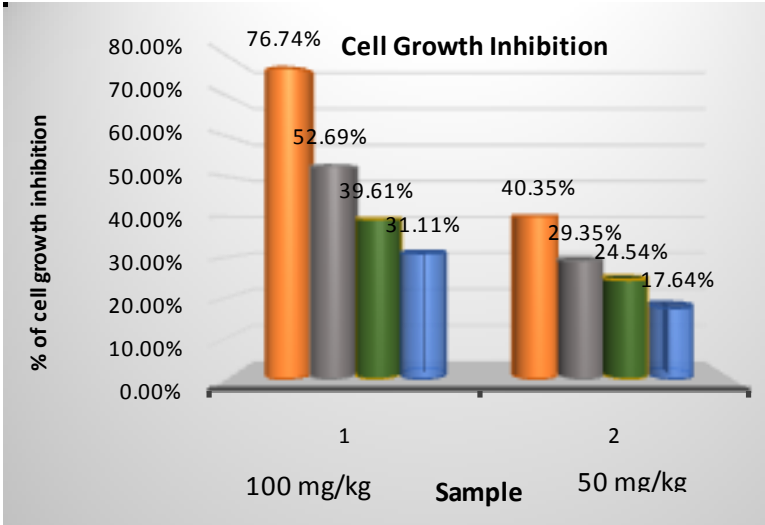

Figure 1: Percentage of cell growth inhibition on day 6 after tumour transplantation

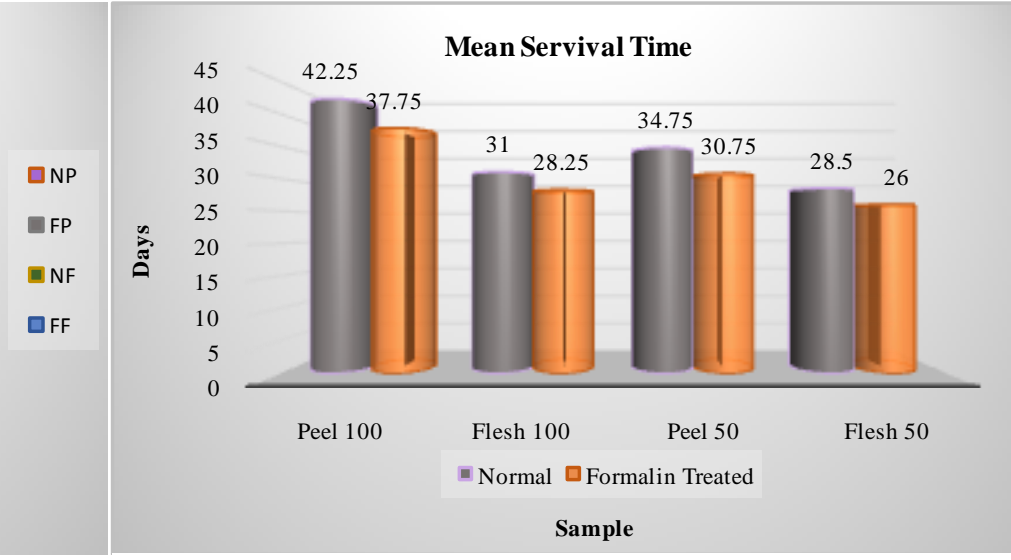

Figure 2: Mean survival time of Swiss albino mice after treated with mango extract

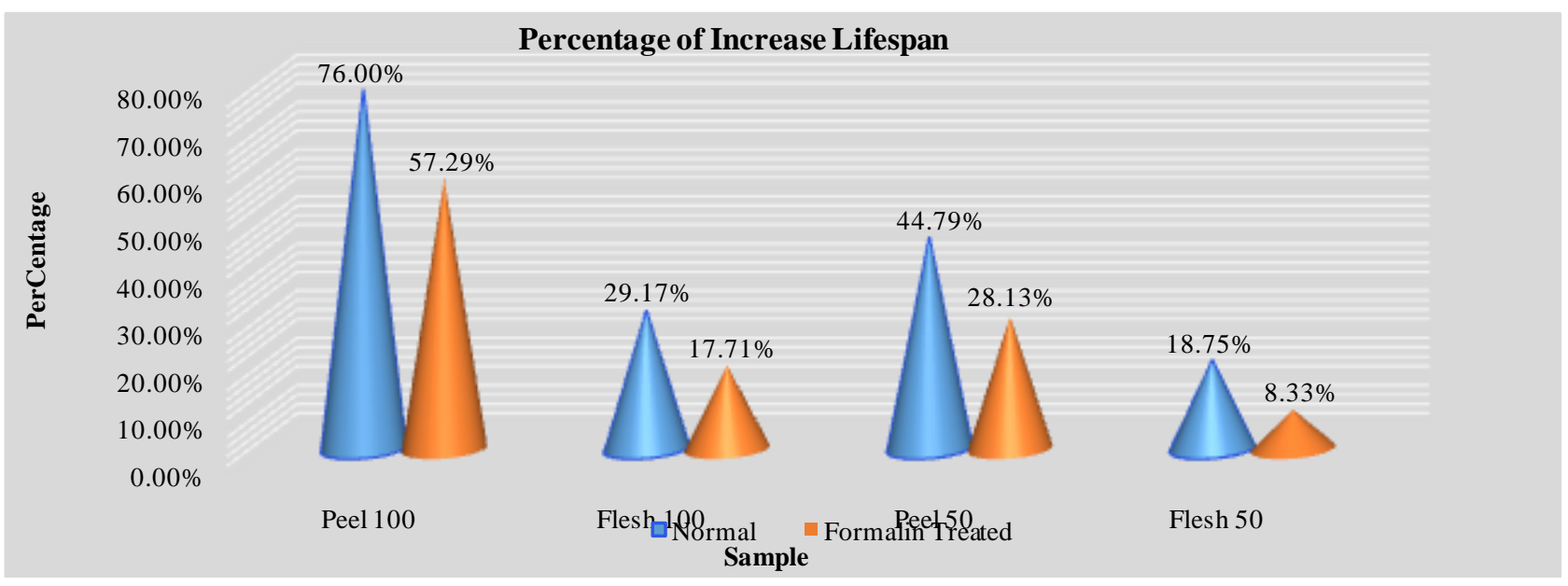

Figure 3:Percentage of increased life span of Swiss albino mice. Here the dose is expressed as $\mathrm{mg} / \mathrm{kg}$ body weight

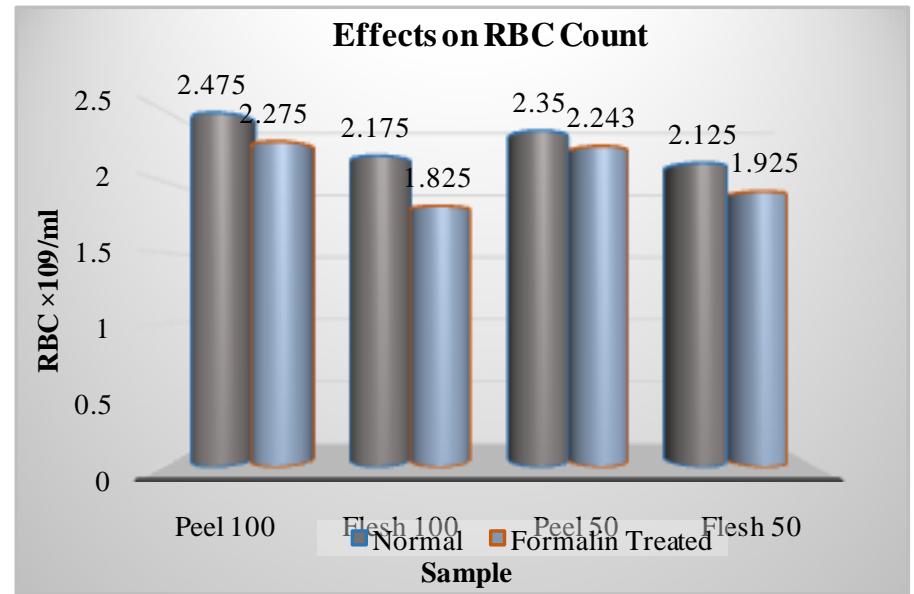

Figure 4: Effects of normal and formalin treated mango peel and flesh on RBC count

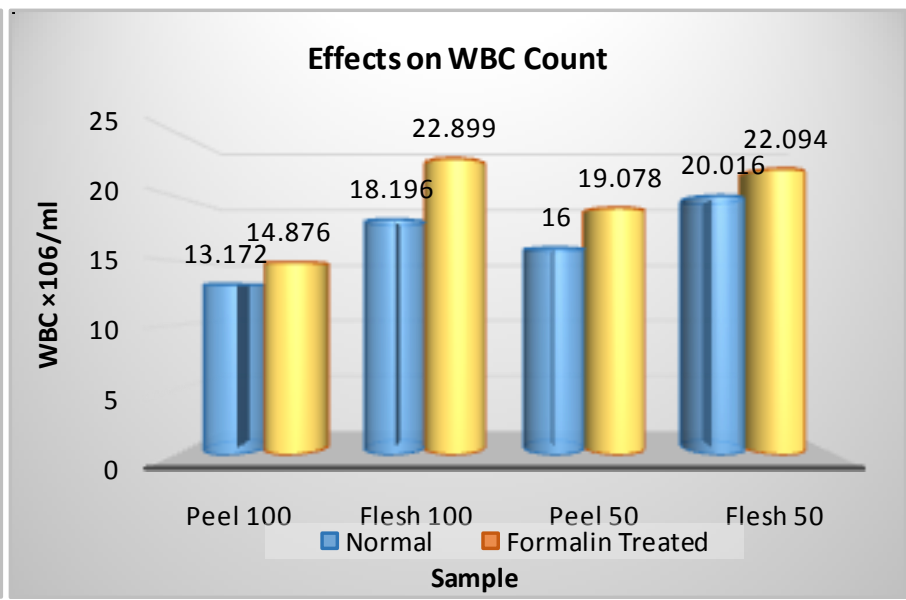

Figure 5: Effects of normal and formalin treated mango peel and flesh on WBC count 


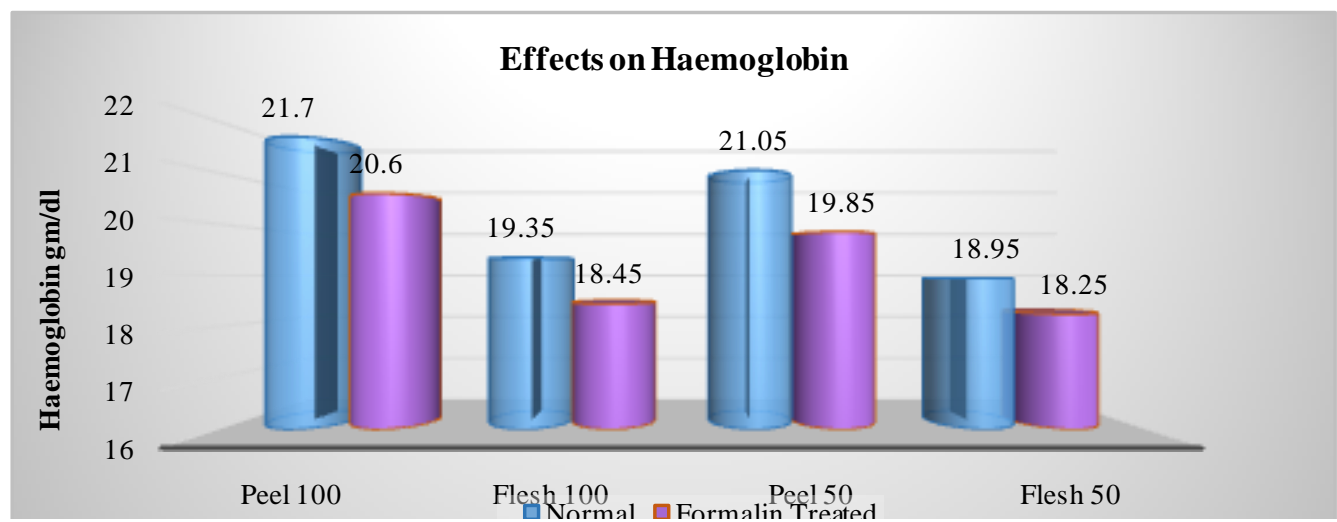

Figure 6: Effects of normal and formalin treated mango peel and flesh on haemoglobin content

\section{DIS CUSS ION}

It has been reported that uncontrolled proliferation of tumour cell decreases the RBC and $\mathrm{Hb}$ content; on the other hand, increases the WBC content ${ }^{[2829]}$. To act as a chemotherapeutic agent, the compound must contain some of the property such as to inhibit the tumour growth, increase life $\mathrm{span}$ and also to correct the haematological parameters ${ }^{[30-31]}$.

In the cell growth inhibition study, normal mango peel (NP) causes maximum inhibition of tumour cell growth among the extract and its inhibition activity increases with increase of dose. As compared to mango peel and flesh it usually finds that mango peel contains antioxidant activity greater than mango flesh ${ }^{[32-33]}$, but when we compare it with formalin treated sample it shows that after treatment with formalin anticancer potentials decreases, which might be suggests that formalin penetrated to the peel of mango and changed the anticancer potential of it. Literature review suggests penetration of formalin in to the specimen is a physical process by which the solution diffuses in to the specimen to reach the innermost layers of cells ${ }^{[34]}$ and when tissues are immersed in formalin, they are rapidly penetrated ${ }^{[35-37]}$.

The survival time of tumour bearing mice is also in increased highest amount in normal mango peel (NP) which is satisfactory as compared to the standard drug bleomycin. The fleshes of both normal and formalin treated have failed to exert satisfactory increase of life span.

From the haematological study it is observed that, the red blood cell (RBC) and haemoglobin ( $\mathrm{Hb})$ is decreased after introduction of EAC cell where as white blood cell (WBC) shows the opposite trend. But treatment with the extracts the RBC is increased except formalin treated flesh (FF) (Figure 4). Normal man go peel (NP) at $100 \mathrm{mg} / \mathrm{kg}$ cause maximum increase. Mice treated with NP has RBC is about $(2.475 \pm 0.035) \times 10^{9}$ where in the normal mice its level is $(3.125 \pm$ $0.035) \times 10^{9}$. After treatment with EAC cell, WBC is increased from the normal value, but when treatment is started it decreases. But in case of formalin treated flesh (FF) it fails to show appreciable change. Normal man go peel (NP) at $100 \mathrm{mg} / \mathrm{kg}$ causes maximum reduction of WBC and the value is $(13.172 \pm 0.11) \times 10^{6}$ where the normal mice contain $(10.153 \pm 0.048) \times 10^{6} \mathrm{WBC}$ (Figure 5). Normal peel (NP) at $50 \mathrm{mg} / \mathrm{kg}$ and formalin treated peel (FP) at $100 \mathrm{mg} / \mathrm{kg}$ also shows appreciable reduction of WBC. In case of haemoglobin, the introduction of EAC cell decreases $\mathrm{Hb}$ content and after treatment by mango extract in all cases it increases and the increase pattern is dose related.

\section{CONCLUSION}

This is the first study about comparative evaluation of anticancer property of mango after formalin treatment. There are several studies about penetration of formalin on animal tissue ${ }^{[35-37]}$ but to our knowledge, there is no data about penetration of formalin in fruits.
From this study, it can be concluded that mango peel is a potent source of antineoplastic agent which is due to the presence of a phenolic compound, mangiferin ${ }^{[23-26]}$. From antineoplastic study, it is found that treatment with formalin markedly reduced antineoplastic activity which may be due to the reduction of antioxidant compounds [38-41].

\section{Acknowledgement}

We would like to give thanks to Ministery of education, Bangladesh for their financial support and also to the Pharmacy Department, Rajshahi University for technical support.

\section{REFERENCES}

1. Hartwell J.L. Plants used against Cancer. Lloydia 1971;32:204-255.

2. Abdullaev F.1., Rivera L.R., Roitenburd B.V., Espinosa A.J. Pattern of childhood cancer mortality in Mexico. Archives of Medical Research 2000; 31(5):526-531.

3. Jemal A., Bray F., Center M.M., Ferlay J., Ward E., Forman D. Global cancer statistics. Cancer journal for clinicians 2011; 61(2):69-90.

4. Lozano R. Global and regional mortality from 235 causes of death for 20 age groups in 1990 and 2010: a systematic analysis for the Global Burden of Disease Study 2010. Lancet 2012; (9859): 2095-2128.

5. International Agency for Research on Cancer. World cancer burden 2012.

http://publications.cancerresearchuk.org/downloads/Product/CS_REPOR T_WORLD.pdf. (12 April 2016)

6. Cancer statistics at a glance. http://www.cancer.ca/en/cancerinformation/cancer-101/cancer-statistics-at-a-glance/?region=on . April 2016).

7. Canadian Cancer Statistics 2012. http://www.phac-aspc.gc.ca/cdmc/cancer/ccs-scc-2012-eng.php. (12 April 2016).

8. Siegel R.L., Miller K.D., Jemal A. Cancer Statistics, 2015. A Cancer Journal for Clinicians 2015; 65:5-29

9. Cancer in Australia. http://www.cancer.org.au/about-cancer/what-iscancer/fact s-and-figures.html. (12 April 2016).

10. Sasco A.J., Secret an M.B., Straif K. Tobacco smoking and cancer: a brief review of recent epidemiological evidence. Lung Cancer 2004; 45(2):3-9.

11. Biesalski H.K., Mesquita B.B., Chesson A., Chytil F., Grimble R., Hermus R.J., Köhrle J., Lotan R., Norpoth K., Pastorino U., Thurnham D. European Consensus Statement on Lung Cancer: risk factors and prevention. Lung Cancer Panel. A Cancer Journal for Clinicians 1998; 48(3):167-176.

12. Schütze M., Boeing H., Pischon T., Rehm J., Kehoe T., Gmel G., Olsen A., Tjønneland A.M., Dahm C.C., Overvad K., Clavel-Chapelon F., Boutron-Ruault M.C., Trichopoulou A., Benetou V., Zylis D., Kaaks R., Rohrmann S., Palli D., Berrino F., Tumino R., Vineis P., Rodríguez L., Agudo A., Sánchez M.J., Dorronsoro M., Chirlaque M.D., Barricarte A., Peeters P.H., van Gils C.H., Khaw K.T., Wareham N., Allen N.E., Key T.J., Boffetta P., Slimani N., Jenab M., Romaguera D., Wark P.A., Riboli E., Bergmann M.M. Alcohol attributable burden of incidence of cancer in eight European countries based on results from prospective cohort study. Bio Med Central 2011;342:1584.

13. Irigaray P., Newby J.A., Clapp R., Hardell L., Howard V., Montagnier L., Epstein S., Belpomme D. Lifestyle-related factors and environmental agents causing cancer: an overview. Biomedicine and Pharmacotherapy 2007; 61(10):640-658. 
14. Kushi L.H., Byers T., Doyle C., Bandera E.V., McCullough M., McTiernan A., Gansler T., Andrews K.S., Thun M.J. American Cancer Society Guidelines on Nutrition and Physical Activity for cancer prevention: reducing the risk of cancer with healthy food choices and physical activity. A Cancer Journal for Clinicians 2006; 56(5):254-281.

15. Park S., Bae J., Nam B.H., Yoo K.Y. Aetiology of cancer in Asia. Asian Pacific Journal of Cancer Prevention 2008; 9(3): 371-380.

16. Brenner H., Rothenbacher D., Arndt V. Epidemiology of stomach cancer. Methods in Molecular Biology 2009; 4:467-477.

17. Pagano J.S., Blaser M., Buendia M.A., Damania B., Khalili K., RaabTraub N., Roizman B. Infectious agents and cancer: criteria for a causal relation. Semin. Cancer Biology 2004; 14(6):453-471.

18. Samaras V., Rafailidis P.I., Mourtzoukou E.G., Peppas G., Falagas M.E. Chronic bacterial and parasitic infections and cancer: a review. The Journal of Infection in Developing Countries 2010; 4 (5):267-281.

19. Roukos D.H. Genome-wide association studies: how predictable is a person's cancer risk? Expert Review of Anticancer Therapy 2009 9(4):389-392.

20. Maltoni C.F.M., Holland J.F. Holland-Frei Cancer Medicine. Chapter 16: Physical Carcinogens. In Bast RC, Kufe DW, Pollock RE .5th ed. Decker. Hamilton, Ont ario 2000

21. Formalin in fruits. The Daily Star, 12 June 2013. http://archive.thedaily st ar.net/beta2/news/formalin-in-fruits/. (26 February 2014).

22. Almost all litchis formalin-tainted. The Daily Star, 12 June, 2014. (12 June 2014).

23. Peng Z.G., Luo J., Xia L.H., Chen Y., Song S. CML cell line K562 cell apoptosis induced by mangiferin. Zhongguo Shiyan Xue Ye Xue Za Zhi 2004; 12 590-594

24. Yoshimi N., Mat sunaga K., Katayama M., Yamada Y., Kuno T., Qiao Z. The inhibitory effects of mangiferin: A naturally occuring glucosylxanthone, in bowel carcinogenesis of male F344 rats. Cancer Letters 2001; 163:163-170.

25. Noratto G.D., Bertoldi M.C., Krenek K., Talcott S.T., Stringheta P.C., Talcott S.U.M. Anticarcinogenic effects of Polyphenolics from mango (Mangifera indica) varieties. Journal of Agricultural and Food Chemistry 2010; 58(7):4104-4112.

26. Kim H., Kim H., Mosaddik A., Gyawali R., Ahn K.S., Cho S.K. Induction of apoptosis by ethanolic extract of mango peel and comparative analysis of the chemical constituents of mango peel and flesh. Food chemistry 2012; $133: 416-422$.

27. Sur P., Ganguli D.K. Tea plant extract (TRE) as an ant ineoplast ic agent Plant a Medica 1994; 60:106-109.

28. Hurter B., Bush N.J. Cancer-related anemia: Clinical review and management update. Clinical Journal of Oncology Nursing 2007; 11:349359.

29. Rosenbaum E.H. Anaemia causes and Treatment. Cancer Supportive Care 2008; 12:67-72.

30. Khanam J.A., Islam M.F., Jesmin M., Ali M.M. Antineoplastic activity of acet one semicarbazone (ASC) against Ehrlich ascites carcinoma (EAC) bearing mice. Journal of the National Science Foundation of Sri lanka 2010; 38:225-231.

31. Perveen S., Islam M.F., Khanam J.A., Yeasmin T. Preventive effect of ethanol extract of Alpinia calcarata Rosc on Ehrlich's ascitic carcinoma cell induced malignant ascites in mice. Asian Pacific Journal of Tropical Medicine 2012; 6:121-125.

32. Berardini N., Fezer R., Conrad J., Beifuss U., Carle R., Schieber A. Screening of mango (Mangifera indica L.) Cultivars for their Contents of flavonol O- and Xanthone C-glycosides, anthocyanins, and Pectin. Journal of Agricultural and Food Chemistry 2005; 53(5):1563-1570.

33. Schieber A., Ullrich W., Carle R. Characterization of polyphenols in mango puree concentrate by HPLC with diode array and mass spectrometric detection. Innovative Food Science and Emerging Technologies 2000; 1:161-166.

34. Grizzle W.E., Fredenburgh J.L., Myers R.B. Fixation of tissues. In: Bancroft JD, Gamble M, editors. Theory and Practice of Histological Techniques. 6th ed. Philadelphia, USA: Elsevier Limited; 2008. pp. 5663.

35. Fox C.H., Johnson F.B., Whiting J., Roller P.P. Formaldehyde Fixation. Journal of Hist ochemistry and Cytochemistry 1985; 33:845-853.

36. Kiernan J.A. Formaldehyde, formalin, paraformaldehyde and glutaraldehyde: What they are and what they do. Microscopy Today 2000; $1: 8-12$.

37. Mason J.T., O'Leary T.J. Effects of formaldehyde fixation on protein secondary structure: A calorimetric and infrared spectroscopic investigation. Journal of Histochemistry and Cytochemistry 1991; 39:225-229

38. Ding M., Lu Y., Bowman L.L., Huang C., Leonard S., Wang L., Vallyathan V., Castranova V., Shi X. Inhibition of AP-1 andneoplast ic transformation by fresh apple peel extract. The Journal of Biological Chemistry 2004; 279:10670-10676.

39. Olsson M.E., Andersson C.S., Oredsson S., Berglund R.H., Gustavsson K.E. Antioxidant levels and inhibition of cancer cellproliferation in vitro by extracts from organically and conventionallycultivated strawberries. Journal of Agricultural and Food Chemistry 2006; 54:1248-1255.

40. Wang S.Y., Feng R, Lu Y, Bowman L, Ding M. Inhibitory effect on activat or protein-I, nuclear factor-kappa B, and cell transformation by extracts of strawberries (Fragariaxa,anas,ca Duch.). Journal of Agricultural and Food Chemistry 2005; 53:4187-4193.

41. Naczk M., Shahidi F. Phenolics in cereals, fruits and vegetables: Occurrence, extraction and analysis. Journal of Pharmaceutical and Biomedical Analysis 2006; 41:1523-1542.

\section{HOW TO CITE THIS ARTICLE}

Parvez GMM, Mosaddik A. Evaluation of anticancer property of mango peel and flesh after formalin treatment. The Journal of Phytopharmacology 2016;5(3):1 12-116. 